NBER WORKING PAPERS SERIES

SECTORAL SHIFTS AND UNEMPLOYMENT IN INTERWAR BRITAIN

S. Lael Brainard

Working Paper No. 3980

NATIONAL BUREAU OF ECONOMIC RESEARCH

1050 Massachusetts Avenue

Cambridge, MA 02138

January 1992

I am grateful to Barry Eichengreen, Doug Elmendorf, Larry Katz, Larry Summers, and Alwyn Young for helpful discussions, to Kishwar Ahmed for research assistance, and to the National Science Foundation for research support. This paper is part of NBER's research program in Labor Studies. Any opinions expressed are those of the author and not those of the National Bureau of Economic Research. 
NBER Working Paper \#3980

January 1992

\section{SECTORAL SHIFTS AND UNEMPLOYMENT IN INTERWAR BRITAIN}

\section{ABSTRACT}

This paper measures the importance of sectoral shifts, as against aggregate shocks and changes in search intensity, in explaining the persistent high unemployment that prevailed in interwar Britain. It develops a new measure of sectoral shifts that captures the arrival of information about reallocation shocks by using the cross-section variation in sectoral stock market excess retums over time. The cross-section variation series accounts for roughly one-quarter of the average level of aggregate unemployment during the interwar period, even after controlling for a variety of shocks to aggregate demand, and for roughly one-half of the variation in unemployment, suggesting an important role for sectoral shifts.

S. Lael Brainard

Sloan School of Management

M.I.T.

Cambridge, MA 02139

and NBER 


\section{Introduction}

Following the First World War, British unemployment rose to unprecedented levels that persisted throughout the interwar period. Unemployment averaged 10.6 percent between 1921 and 1938, more than double the average during the five decades preceding the First World War, and five times that in the two decades following the Second World War. The prolonged episode of high unemployment in the interwar period was unusual in several respects: it was accompanied by extensive shifts of output between sectors and regions and by moderate growth in both industrial production and GNP, and it diverged markedly from contemporaneous patterns of unemployment in other industrial economies.

Not surprisingly, this episode of high unemployment has provided fertile ground for competing theories of unemployment. The primary contenders in this debate, as in the debates over recent unemployment, are adverse aggregate fluctuations, increased search activity, and sectoral reallocation shocks. Those who emphasize aggregate fluctuations argue that firms across a broad crosssection of sectors laid off workers in response to economy-wide adverse demand shocks associated with monetary contraction. The proponents of the search hypothesis contend that an increase in unemployment benefits enabled workers to be more selective in their job searches, leading to a sharp increase in search activity on aggregate. Sectoral shifts proponents argue that a massive, permanent shift in the sectoral pattern of demand led to higher unemployment through timeconsuming reallocation of capital and labor between sectors. 
In this paper, 1 formalize and test the role of sectoral shifts in explaining British interwar unemployment, relative to greater search intensity and adverse aggregate shocks. To this end, I develop a series to measure the incidence of sectoral reallocation shocks, based on the cross-section variation (CSV) in industry stock market excess returns over time. ${ }^{1}$ This series has two advantages over reallocation measures based on dispersion in ex post employment flows, such as that proposed by Lilien (1982). First, it measures the arrival of the shocks directly, since stock prices move immediately and only once in response to the arrival of information about future profitability. Second, the series relies on a capital asset pricing model (CAPM) formulation of excess returns to isolate movements in stock prices that are attributable to reallocation news from those attributable to shocks to the aggregate economy.

The CSV series is included in unemployment equations as a proxy for reallocation shocks, along with variables that control for aggregate shocks and changes in search costs, with interesting results. The effect of an increase in CSV is to raise unemployment with a lag of 1 to 2 years. The CSV series accounts for roughly one-third of unemployment on average in the interwar period, after controlling for the effects of aggregate shocks. It accounts for over 40 percent in the first half of the 1930 's, rising to 50 percent in 1932. CSV also accounts for a substantial portion of the variation in unemployment.

The paper proceeds as follows. Section II describes the principal competing explanations of unemployment, as they are applied to the British interwar debate. 
Section III formulates a sectoral reallocation explanation of unemployment that hinges on imperfect mobility of labour and capital, and presents anecdotal evidence on the British interwar economy in its support. Section IV discusses alternative empirical measures of sectoral shifts, and argues for a measure that relies on stock market excess returns; it then describes the construction of the CSV series and other data. Section $V$ presents the empirical findings. Section $V I$ concludes.

\section{Search, Aggregate Fluctuations, and Sectoral Shifts}

Explanations of the high interwar unemployment rate can be grouped broadly into three categories, reflecting the general macroeconomic debate over the nature of unemployment. The search hypothesis attributes the increase in unemployment levels to an increase in the opportunity cost of labor that induced workers moving between jobs to spend longer in search activities. It has been advanced as an explanation for British interwar unemployment by Benjamin and Kochin (1979). According to their account, an increase in the benefits-to-wage ratio provided under unemployment insurance, from 16 percent in 1920 to over 38 percent by 1925, raised the opportunity cost of labour and ratcheted up the natural rate of unemployment. Benjamin and Kochin's empirical results suggest that over 30 percent of unemployment was chosen voluntarily in response to this increase in benefits. These findings have been challenged by a number of authors, in particular by those who see the change in the benefits-wage ratio as itself a response to adverse aggregate shocks. ${ }^{2}$ 
The aggregate fluctuations hypothesis attributes high levels of unemployment to adverse aggregate shocks that caused firms across a wide range of sectors to lay off workers temporarily. There are several variants of this hypothesis, which commonly hinge on nominal stickiness either in wages or prices. In the British interwar context, Hancock (1962) attributes the persistent high unemployment to deflationary monetary policies pursued by a government committed to restoring the sterling prewar parity in order to maintain U.K. dominance in world financial markets. Crafts et. al. (1984) conclude that an adverse demand shock to the global economy caused a large decline in demand for British staple exports, which depressed aggregate income and led to a contraction in labour demand throughout the economy.

Both the search and aggregate fluctuations hypotheses attribute prime causality to aggregate forces that affected a broad cross-section of sectors similarly. In contrast, a third set of explanations emphasizes sector-specific shocks as the locus of the unemployment problem. Sectoral reallocation leads to an increase in aggregate unemployment if the process of matching workers from adversely affected sectors to jobs in favorably affected sectors is time-consuming, or if job creation takes longer than job destruction due to adjustment costs in investment. 


\section{Sectoral Shifts and Imperfect Mobility}

The sectoral reallocation hypothesis fits well with the peculiar economic conditions that accompanied the persistently high unemployment in interwar Britain. The first was growth in the economy overall: between 1920 and 1938, real GNP grew at an annual rate of roughly 2 percent on average, while industrial output grew at 3 percent annually. The second notable fact was significant disparity between regions and between sectors in growth and employment rates. Landes (1969) attributes this disparity to a set of profound shifts in the industrial base that were concentrated in this period. By his account, these shifts were sufficiently profound and disruptive to warrant the label, "the second industrial revolution".

Aldcroft (1969) was the first to advance a sectoral shifts explanation of British interwar unemployment. According to his account, Britain emerged from the First World War overcommitted to its traditional export industries, at a time when world demand for these goods was falling, and firms in other industrial countries were investing heavily in "second revolution" industries. The decline in demand for Britain's traditional exports, coupled with rising internal demand for new products, induced a massive shift of resources away from the "first revolution" industries to the fledgling "second revolution" industries. Aldcroft argues that the shift in the sectoral composition of output led to an increase in aggregate unemployment because the expanding sectors were more capital intensive than the contracting sectors. 
There have been several challenges to Aldcroft's claim that sectoral shifts resulted in an aggregate net change in factor intensity. Broadberry (1983) shows that overall total factor productivity growth in the interwar period was unexceptional, controlling for changes in the quality of the labour force. He further finds scant evidence linking rationalization to a decline in labour intensity. Von Tunzelman (1982) shows that the new industries were more rather than less labour-intensive than the old by roughly one-third, so that equal rates of output growth in the new industries and contraction in the old would have resulted in more rather than less labour absorption. Dowie shows that productivity growth rates were not consistently different in new and old industries; some of the staple industries experienced productivity growth of the same magnitude as the new industries (Broadberry, 1983).

It is important to note that these arguments do not challenge the claim that there were extensive shifts among sectors in labour demand, and indeed there is abundant informal empirical support of extensive sectoral reallocation. An alternative account of sectoral shifts that is consistent with both sets of facts posits imperfect intersectoral factor mobility as the transmission mechanism whereby reallocation shocks generate aggregate unemployment. ${ }^{34}$ It starts from the premise that the economy is subject to permanent shocks that change the sectoral pattern of demand, inducing shifts in the equilibrium distribution of resources between sectors. In the presence of imperfect intersectoral mobility, adjustment to an exogenous shock that changes the equilibrium distribution of 
capital raises unemployment, even when the new equilibrium attains a higher level of aggregate income. Put simply, if steel mills cannot cheaply and quickly be converted into chemical plants, or experienced steel workers cannot costlessly and immediately switch to chemical production, steel workers will experience unemployment when there is a long-term contraction in the steel industry, even if it is more than offset by expansion in the chemical industry.

Imperfect intersectoral mobility may be caused by adjustment costs in investment; industry-specific physical capital; and industry, location, or occupationspecific human capital. Only some subset of these factors is necessary, but there is evidence that all three were important in the British interwar economy.

In the interwar period, a number of large shocks have been identified as inducing an extensive and sustained reallocation of resources among sectors. Firms in Britain's traditional export industries faced stiff new competition from second-tier countries that had been large import customers prior to the war, and had since expanded their productive capacities under the enforced autarchy of the war years. This shift in demand was aggravated by a terms-of-trade shock caused by the return to the prewar sterling parity to gold in 1925 . The price shock was extremely damaging to the international competitiveness of Britain's established export industries.

The decline in export demand in the staple industries was particularly severe during the Depression years. Crafts et. al. (1984) note that exports was the component of aggregate demand that sustained by far the largest decline both 
relatively and absolutely during the Depression in Britain. This was in sharp contrast to the U.S., where consumption and investment dominated. Between 1929 and 1932, British exports fell by 32 percent, while investment fell by 19 percent, and consumption actually rose by 2 percent. In absolute terms, the decline in exports ( $L 317$ million in 1938 prices) was more than triple that in investment. Since sectors varied widely in their shares of production for export, the effect of the severe contraction in export competitiveness was distributed very unevenly among sectors. Using input/output tables to calculate the differential effect of export demand on employment among industries, Crafts et. al. find there were tremendous differences. For instance, in one mature industry that experienced an overall employment decline of 18 percent, the decline in export demand accounted for employment contraction of twice the net amount. In contrast, only $1 / 3$ of the 7 percent reductions in employment in the emerging motor vehicles and aircraft industries was attributable to decreased foreign demand.

At the same time, domestic demand for durable goods such as housing and automobiles surged, reflecting pent-up demand carried over from the war years and the emergence of new products attributable to technoiogical advances. The period 1924-37 stands out between the years of 1856 and 1973 as having extremely high growth in domestic absorption relative to total output. The strength of the impetus provided by domestic absorption as against export demand for the manufacturing sector also stands out in this period. Domestic absorption 
contributed twice as much stimulus as in other periods, while the contraction in export demand outweighed that in any other period by a factor of two, with the exception of 1963-72, which was comparable (Matthews et al.).

These shifts in demand were mirrored on the production side by concentrated disinvestment in first revolution industries, and increased investment in second revolution industries. Firms in the U.S., Germany, and other industrial countries had made substantial investments in emerging industries such as chemicals, cars, and aircraft in the early 1900's, and they moved quickly to exploit the technological advances that had been made under the stimulus of war-time production. British investment in the new industries during the prewar period had been more tentative, owing in part to British dominance in the maturing first revolution industries, so that British firms had to make up for lost time in the postwar years.

The period 1924-37 in Britain stands out as having by far the highest growth rate of manufactures among the periods between 1856 and 1973, against a background of moderate overall growth. The growth of manufacturing share in output was nearly double that of any other period. The growth rate of total factor productivity in manufacturing was also extremely high in the interwar period: double that during the first industrial revolution (1856 to 1873), and triple that of the four decades leading up to the First World War (Matthews et. al.). This rapid growth suggests substantial shifts of factors into high growth industries.

Although it is difficult to find direct evidence of sectoral specificity in human 
capital, there is substantial evidence that labour markets were geographically segmented in the interwar period. ${ }^{5}$ Disparities in industry growth rates in this period were accompanied by large disparities among geographic regions in employment growth. The mature export industries were clustered around ports and coal mines in the north and the west, while the new industries tended to be located near growing concentrations of domestic demand in the south and the east. As Matthews et. al. point out, the regional ranking of labour force participation and unemployment rates reversed itself between the prewar and interwar periods. In 1881 and 1921, labour force participation rates were low in the South East (including London), and high in the East Midlands, Yorkshire, the North West, and Wales. By 1929, the reverse was true, and the new pattern proved persistent. Table 1 establishes that regional unemployment rates underwent a similarly sharp reversal.

The reallocation hypothesis is also substantiated by observations made at the time that severe unemployment in some industries coexisted with labour shortages in others. Thus, for instance, the 1927 Blanesburgh Committee on Unemployment Insurance concluded:

Some of us have been impressed by the difficulty which certain growing industries experience in meeting their labour requirements, even though there are unemployed men in other industries where their services are not likely again to be required, at any rate for a considerable time (cited in Hancock (1962)). 


\section{Data}

\section{i. Measuring Sectoral Shitts}

These observations are suggestive but far from conclusive. A rigorous test of the importance of sectoral reallocation in response to permanent shocks to the equilibrium distribution of capital must distinguish empirically between the idiosyncratic effects of aggregate and sectoral shocks. Note that in the account I have developed, it is not necessary that aggregate fluctuations play no role in the unemployment story. It is critical, however, that the effects of sectoral and aggregate shocks be distinguishable, and independently significant; the key is to find a clean measure of sectoral reallocation shocks.

Lilien (1982a and b) proposed a measure of the sectoral dispersion in employment growth as a proxy for the degree of sectoral shifts in the U.S. postwar economy. If the movement of workers between sectors takes time, then stochastic shocks to the sectoral pattern of demand will induce an increase in the dispersion of sectoral net employment growth rates, and in aggregate unemployment. Even with constant aggregate demand, the unemployment rate will fluctuate as long as the variance of the process generating fluctuations in individual market demands changes over time.

Following this logic, Crafts et. al. developed an employment dispersion index for the interwar period in Britain in order to test the sectoral shifts hypothesis against the aggregate fluctuations hypothesis. They are led to conclude that sectoral shifts had little independent significance in explaining the high 
unemployment of the interwar years, when measured against aggregate demand shocks.

However, their conclusions depend on the employment dispersion series being a good proxy for sectoral shifts; this claim has been convincingly challenged in the U.S. postwar context by Abraham and Katz (1986). Abraham and Katz argue that sectoral employment dispersion may rise in response to aggregate fluctuations as well as sectoral shifts, as long as sectoral sensitivities to aggregate fluctuations differ. ${ }^{\circ}$

A related difficulty with an employment dispersion measure is that it measures the employment response to a shock rather than the arrival of the shock itself. Thus, even if sectors are identical in terms of the magnitude of their cyclical responsiveness, employment dispersion will be a diluted indicator of reallocation shocks if sectors differ in their rate of response.

To overcome these ambiguities, I propose an alternative measure of sectoral reallocation shocks that is constructed from the dispersion of industry stock market excess returns over time. This measure has several virtues over a measure based on employment flows. First, it measures the arrival of the shocks themselves rather than the employment response. Given sector-specific capital, a reallocation shock should register first in an increase in the sectoral dispersion of returns to capital, reflecting the shift in the long-run equilibrium distribution of capital. Given efficient markets, the arrival of new information about the expected present discounted value of the stream of profits from incremental investment in an 
industry should be reflected in a one-time change in an industry's stock market return. In contrast to industry employment growth, which changes gradually over time, industry returns should respond immediately and completely to the arrival of new information, yielding a much clearer temporal pattern.

Second, the CAPM provides theoretical underpinnings that permit the decomposition of an industry's return into an idiosyncratic shock component (the excess return) and an aggregate shock component (the correlation with the market portfoliol. Thus, the variance of sectoral excess returns should closely reflect the degree of dispersion in expected future profitability across sectors at each point in time, and foreshadow the degree of future intersectoral capital movements.

As long as the correlation between the demands for labour and capital is of the same sign in a majority of industries, and is fairly stable within industries over time, high dispersion in excess returns will anticipate an increase in intersectoral labour reallocation. Given a positive cross-elasticity of demand for capital and labour in an industry, an increase in the return on capital signals the desirability of augmenting labour as well as capital. ${ }^{7}$ The unemployment response to an increase in sectoral returns dispersion will be greater the greater is the rate of job destruction relative to job creation, the more sector specific is human and physical capital, the greater is the geographical dispersion of growing and declining sectors, and the greater is the cross-elasticity of factor demands. 


\section{ii. Construction of the CSV Series}

The cross-section variation (CSV) series is constructed from the stock prices of 103 companies in 11 industries from 1920 to 1938 at annual frequencies. Industry price indices were constructed from company stock prices, using a report by the London and Cambridge Economic Service (1931) on the construction of their stock market index to identify the most representative companies in each industry. Using the company values from this report as weights, and company stock market prices reported in the London Times (on the same day each year), price indices were constructed for 11 industry stock portfolios. The indices are adjusted for discontinuities (reporting changes, mergers, entrances and exits from the stock exchange), incomparability of stock prices between companies, and missing data.

The return for industry $\mathbf{i}$ at time $t, R_{i t}$, is computed from company stock prices, $P_{a t}^{i}$ and company values $v_{c t}^{i}$ :

$$
R_{t}=\sum_{c=1}^{n_{t}^{\prime}} \frac{v_{c t}^{i}}{\sum_{c=1}^{n_{t}^{\prime}} v_{c t}^{l}} \ln \left(\frac{P_{c t}^{i}}{P_{c-1}^{l}}\right)
$$

where $n_{t}^{i}$ is the number of companies in industry $i$.

The excess return for industry $i$ at time $t, \epsilon_{\mathrm{t}}$, is computed as the residual from a CAPM regression of individual industry returns against the market return:

$$
R_{i t}=\alpha_{i}+\beta R_{m t}+\epsilon_{i t}
$$


where $R_{m x}$ is the return on the market portfolio in year $t$. The cross-section variation series, $\mathrm{CSV}_{t}$ is formed as the variance of industry excess returns, weighted by employment shares, $e_{i n}$, computed from employment data in Feinstein (1972):

$$
C S V_{t}=\sum_{i=1}^{N_{t}} \frac{e_{i t}}{\sum_{i=1}^{N_{t}}}\left(e_{i t}-\overline{\epsilon_{i}}\right)^{2}
$$

The employment weights adjust for the magnitude of the impact of a change in an industry's excess return on aggregate employment.

The CSV series is reported in the Appendix and is shown in Figure 1a. The statistics for the CSV series are given in Table 2. There is some positive serial correlation in the series, but it is small and declines quickly.

There are a number of caveats in using CSV as a proxy for reallocation shocks, chief among them that the relationship between the demands for labour and capital could go in different directions for different subsets of industries in response to certain sectoral shocks. Von Tunzelman's finding that capital-labour ratios were fairly similar across the new and old industries provides evidence against this possibility. In addition, an OLS regression of excess net employment growth against excess returns by industry over time (not reported) confirms that the relationship is positive, although the explanatory power of the excess return is low. It also provides some evidence against the possibility that the informativeness of the CSV series is compromised by extreme differences between 
industries in investment or hiring rates, which would be reflected in an ambiguous lag structure.

Potential flaws are also inherited through the reliance on the CAPM model; there is an extensive literature on the theoretical and empirical merits and flaws of the CAPM, which I will not review here. ${ }^{8}$ I address the criticism that the return on the market does not adequately capture the full range of aggregate shocks by forming an alternative excess return dispersion series using a multifactor model of stock returns. This series was formed by adding the log change in the real money supply, the change in real government spending, and a dummy to capture the 1931 currency revaluation to the independent variables in equation (2). For most industries, almost all of the explanatory power is in the market return. The series formed from the residuals of this equation is very similar to the CSV series, with a cross-correlation of 0.93 , and performs similarly in the aggregate equations, so I do not report the results below.

The series would also be distorted if there were systematic differences in debt/equity ratios between industries or over time. Since a large share of investment capital was in the form of bank debt and the equity market was growing rapidly during this period, it is possible that the average debt-equity ratio was declining. In the absence of data on industry debt/equity ratios, I include the return on the market portfolio as a (rough) control for the aggregate debt/equity ratio in several of the equations. 


\section{iii. Other Series}

The dependent variable, UNN, is formed as the ratio of the aggregate unemployment rate to the aggregate employment rate (Source: Feinstein (1972)). The statistics for the unemployment series are given in Table 2; notice that there is strong positive first-order serial correlation. Figure 1a shows the CSV series and Figure lb shows the aggregate unemployment rate over the period 1921-1938. There is a steep increase in CSV in the years 1929 to 1930 , followed one year later by a sharp spike in the unemployment rate. Between the years 1923 and 1931, the unemployment series follows a one-year lag of CSV quite closely, but after the peak in the CSV series in 1931, CSV reverses direction sooner than does unemployment.

The empirical tests use various controls for aggregate shocks. The reported equations include a control for aggregate monetary shocks, DRM, which is computed as the annual log change in the real money supply (Source: Friedman and Schwartz (1982)). I also used alternative measures of monetary shocks, including a 3-month Treasury interest rate series, and an unanticipated money series, similar to that favored by Lilien, and by Crafts et. al., and originally proposed by Barro (1978). The alternative measures yield similar results, so I do not report them.

I control for the aggregate effects of the return to the prewar sterling parity in 1925 and the subsequent abandonment of the gold standard in 1931 with a dummy variable, called GOLD. 
Following Crafts et. al., I also control for terms-of-trade shocks by including the log change in the real value of exports, called DEX (Source: Feinstein (1972)).

I control for shocks to the aggregate stock market by including the one-year real return on the market portfolio, called MRET (Source: London Times, and London and Cambridge Economic Service).

I tried various controls for the effects of fiscal policy, including log changes in the real value of the government debt, and changes in the real value of total government expenditures. Again, the choice of fiscal variable made no difference to the significance of the CSV series, so I report only the equations with changes in real government expenditure, called DGOV.

I test against the search hypothesis by including the benefits-to-wage ratio, called BW, following Benjamin and Kochin (Source: Burns (1941) for benefits; Chapman (1953) for wages).

In addition, 1 construct an employment dispersion series along the lines proposed by Lilien in order to compare it with the CSV series directly. The equation for the employment series, called EMP, is:

$$
E M P_{,}=\sum_{i=1}^{26} \frac{e_{i t}}{\sum_{i=1}^{26} e_{i t}}\left[\ln \left(\frac{e_{t}}{e_{i k-1}}\right)-\ln \left(\sum_{i=1}^{26} \frac{e_{i k}}{e_{i k-1}}\right)\right]^{2}(4)
$$

The employment data includes 13 manufacturing industries and 13 nonmanufacturing sectors, including government (Source: Feinstein (1972)). 
Series

Name Description

UNN Ratio of Aggregate Unemployment Rate to Employment Rate

CSV Employment-weighted Variance in Industry Excess Returns

DRM Log Change in Real Money Supply

DEX Log Change in Real Export Revenues

DGOV Change in Real Government Expenditures

MRET Return on the Market Portfolio

BW Ratio of Unemployment Benefit to Average Wage

EMP Employment-weighted Variance in Sectoral Employment Growth

GOLD Dummy Variable for Return to Prewar Parity

\section{Measuring Sectoral Shifts Unemplovment}

i. Time Soecification

I start by considering the appropriate time specification of the unemployment

equation. Since the true temporal structure of aggregate unemployment is an

extensively researched and as yet unresolved issue, Table 3 reports a variety of time specifications of the basic unemployment equation. Column 1 reports the base equation in levels with CSV and DRM as the independent variables:

(5)

$$
U N N_{t}=\beta_{0}+\sum_{i=0}^{2} \beta_{1 i} C S V_{t-i}+\sum_{i=0}^{1} \beta_{2} D R M_{t-i}+\mu_{t}
$$

The Durbin-Watson statistic suggests the possibility of serial correlation, consistent with the high autocorrelation of the UNN series.

Accordingly, Column 2 uses the first lagged value of the dependent variable 
to control for serial correlation:

(6)

$$
U N N_{t}=\beta_{0}+\sum_{t=0}^{2} \beta_{1} C S V_{t-1}+\sum_{t=0}^{1} \beta_{2} D R M_{t-t}+\rho U N N_{t-1}+\mu_{t}
$$

The inclusion of lagged unemployment improves the fit of the equation, and increases the explanatory power of the contemporaneous and first lagged values of CSV, while it decreases both the size and precision of the coefficient on the second lag of CSV. The contemporaneous and first lagged values of CSV enter positively and significantly at the 5 percent level. DRM enters with the expected sign, but is insignificant.

Column 3 reports the $A R(1)$ specification:

$$
\text { (1) } U N N_{t}-\rho U N N_{t-1}=\beta_{0}+\sum_{i=0}^{2} \beta_{1 i}\left(C S V_{t-i}-\rho C S V_{t-i-1}\right)+\sum_{i=0}^{1} \beta_{2 i}\left(D R M_{t-i}-\rho D R M_{t-1-1}\right)+\mu_{t}
$$

The first-order serial correlation coefficient is large and significant. However, the explanatory power of the CSV series changes very little: the contemporaneous value of CSV is somewhat less significant, while the size and significance of the second lagged value rises. DRM remains insignificant.

I also include a difference specification of the unemployment equation since the possibility of a unit root has not been decisively rejected in related research: 
(8)

$$
\Delta U N N_{t}=\beta_{0}+\sum_{i=0}^{2} \beta_{1 i} C S V_{t-1}+\sum_{t=0}^{1} \beta_{2} D R M_{t-1}+\rho \Delta U N N_{t-1}+\mu_{t}
$$

where $\triangle U N N$ denotes the first difference of unemployment. The results are reported in Column 4. The difference specification worsens the fit of the equation substantially, and the first lagged value of the difference in unemployment is insignificant. The contemporaneous and first lagged values of CSV continue to enter positively, at a lower level of significance, while the second lagged value of CSV becomes insignificant. In contrast, the first lagged value of DRM gains in significance, and both lags have the expected sign.

The explanatory power of the CSV series appears fairly robust to variations in the time specification: changes are reflected primarily in the relative importance of different lags, and both the first lag of CSV and the sum of the contemporaneous and two lagged values of CSV (not reported) are almost uniformly positive and significant. I confine attention to the first lag specification for the remaining empirical results; this specification seems most appropriate because it controls for autocorrelation without being overly restrictive, it achieves the best fit, and it is most comparable to related work in the area.

\section{ii. Unemolovment Equations}

Table 4 reports regressions that add different combinations of independent variables to Equation (6) to control for aggregate shocks. Column 1 reports 
unemployment regressed against contemporaneous and two lagged values of CSV and its own first lag. The equation suggests there is a strong and significant positive relationship between unemployment and CSV.

Figure 2 shows the impulse response of unemployment to a CSV shock, associated with the univariate equation in Column 1. The impulse is a one standard deviation shock to the error term of a second order autoregression of CSV. Unemployment rises by 0.7 percentage points contemporaneous with the CSV shock, an additional 1.1 percentage points in the second year, and the increase peaks at 2.0 percentage points 3 years out. The response of unemployment falls gradually after the peak, approaching zero after 6 years. Figure 2 also shows standard error bands for the response function; the response is statistically significant throughout the first 6 years.

Column 2 adds the contemporaneous and first lagged value of real money growth to the regression as an aggregate control. There is only a marginal improvement in the fit of the equation. The coefficients on both values of DRM are negative, as expected, but neither is statistically significant. The inclusion of DRM lowers the size and significance of the coefficients on all three values of CSV slightly, but all three remain positive and statistically significant. The poor performance of the money series may be attributable to the endogeneity of monetary policy.

The contemporaneous and first lagged value of the return on the market portfolio are included in Column 3. The addition of MRET improves the fit of the 
equation markedly; the coefficients on both the contemporaneous and lagged values have the expected sign, although only the latter is significant. The coefficients on all three values of CSV fall in response to the inclusion of MRET. but the contemporaneous and first lagged value continue to be highly significant, and an $F$ test on the exclusion of CSV achieves significance of 3 percent. Thus, it appears that CSV exerts an influence on unemployment independent of its correlation with the aggregate market.

Column 4 adds a dummy variable to control for the effects of aggregate shocks associated with the return to the prewar parity in 1925 and its subsequent abandonment in 1931. The inclusion of GOLD improves the fit of the equation significantly; the intercept shifts up substantially, and the magnitude and significance of the coefficients on most of the independent variables rise. The coefficients on CSV increase in both size and significance, and their exclusion can be rejected at less than 1 percent.

Column 5 replaces the market and gold standard variables with the contemporaneous and first lagged value of the log change in real exports. 1 include this series to permit comparison with the findings of Crafts et. al.; they use real exports to capture the effects of terms-of-trade shocks, along with an employment dispersion series as a proxy for sectoral shifts. Crafts et. al. find that the export series is highly significant and the employment dispersion series is not, and from this conclude that aggregate rather than sectoral shocks were the key determinant of interwar unemployment. Here, in contrast, the CSV series retains substantial 
explanatory power with the inclusion of DEX, and the inclusion of DEX improves the fit of the equation only marginally. The coefficients on all three values of CSV fall, but the first and second lagged values remain significant at the $\mathbf{5}$ and 10 percent levels respectively, and an F test on the exclusion of CSV fails at 11 percent significance. The coefficient on the contemporaneous value of DEX is negative and statistically significant, while that on the lagged value is insignificant. The exclusion of DEX can be rejected only at 24 percent significance.

It is difficult to interpret the results on the export series as rejecting either the aggregate or sectoral shifts hypothesis. To the extent that changes in aggregate exports reflected aggregate shocks, such as terms-of-trade shocks associated with the return to the prewar parity, or the decline in world income associated with the Depression, it can be interpreted as an aggregate control. But to the extent that the export variable reflects shifts in relative sectoral demands due to increased foreign competition in selected industries, it can be interpreted as a sectoral reallocation variable. The sign of the coefficient on the contemporaneous value of DEX is consistent with an aggregate interpretation, while the high correlation of the DEX series with both aggregate and sectoral variables suggests elements of both.

Column 6 includes the market return and the gold standard variable, along with the export series. The results are very similar to those excluding the export series, with the sole exception that the coefficient on the contemporaneous value of the market return gains in significance, while that on exports shifts from the 
contemporaneous to the lagged value, consistent with the high correlation between the export and market return series. The coefficients on cross-section variation gain in magnitude, and remain highly significant.

Figure 3 shows the impulse response functions associated with the multivariate equation reported in Column 6 . The impulses are one standard deviation shocks to the error term of the second order autoregression of each of the independent variables: DRM, MRET, DEX, and CSV. The inclusion of the aggregate controls reduces the magnitude of the responsiveness to CSV, but the response remains significant throughout the first four years. Unemployment rises $\mathbf{1 . 4}$ percentage points in the first year following a CSV shock, and peaks at $\mathbf{1 . 5}$ percentage points two years out (Figure 3a). The response falls rapidly following the peak.

The response to the aggregate shocks is much more modest (Figures 3b,3c,3d). Unemployment falls by 0.5 percentage points over two years in response to a one standard deviation increase in exports. It essentially returns to 0 the following year. A positive monetary shock is associated with a transitory increase in unemployment of 1.3 percentage points, followed by a steep decline of 2.5 percentage points over the following year. Unemployment then rises gradually, reaching 0 at 4 years out. A shock to the market induces an immediate drop in unemployment of 0.3 percentage points that lasts for an additional year. Unemployment then rises, peaking at 0.3 percentage points 4 years out, and then fluctuates shallowly about 0 . 
Returning to Table 4, Column 7 includes the log change in real government expenditures as an aggregate control. The inclusion of DGOV worsens the fit of the equation, and the coefficient on neither the contemporaneous nor lagged value differs significantly from 0 . The coefficients on all three values of CSV rise, and all three are significant. The low explanatory power of DGOV is not surprising, since there was little variation in fiscal policy through most of the interwar period. The inclusion of alternative measures of fiscal stimulus, such as the net change in public debt yields similar results, so I do not report them.

Column 8 includes the contemporaneous and first lag of the benefits-towage ratio to capture changes in the opportunity cost of labour. The contemporaneous value of the BW series has the expected sign, but neither of the BW terms is significant, and the fit of the overall equation deteriorates slightly. The inclusion of BW slightly lowers the coefficients on all three values of CSV, but the contemporaneous and first lagged value remain significant, and the exclusion of $\mathrm{CSV}$ is rejected at 2 percent significance.

I estimate similar equations replacing the cross-section variation series with the employment dispersion series; the results are largely consistent with Crafts et. al., so I do not report them here. In an equation with money and lagged unemployment, the contemporaneous and first lagged values of EMP are positive and statistically significant. When the export variable is added to the equation, however, the employment dispersion series is rendered insignificant, and the fit of the overall equation improves markedly. The contemporaneous value of DEX is 
negative and significant, consistent with an aggregate shock interpretation. EMP also loses its explanatory power when the return on the market is included in place of the export series.

Column 9 reports an equation that includes both employment dispersion and cross-section variation simultaneously. The inclusion of EMP improves the fit of the equation only marginally relative to Column 2 . The coefficient on the contemporaneous value of CSV rises and remains statistically significant, while the first lag becomes insignificant. In contrast, the addition of CSV improves the fit of the EMP equation substantially. The coefficient on the contemporaneous value of EMP becomes insignificantly negative, while the coefficient on the first lag rises and remains significant. The exclusion of CSV is rejected at 3 percent significance, compared with 16 percent for the exclusion of EMP.

Overall, Table 4 establishes that aggregate unemployment rises in response to a cross-section variation shock; this is robust to the inclusion of a variety of controls for aggregate shocks and for changes in the opportunity cost of work. The evidence suggests that reallocation shocks were important in raising unemployment in the interwar period, independent of aggregate shocks and labour supply shocks. In contrast, the positive influence of employment dispersion on unemployment appears strongly correlated with that of aggregate variables, such as exports and the market return. 


\section{iii. Unemolovment Decomposition}

Figure 4 shows a decomposition of total unemployment into the share attributable to CSV shocks, and that explained by a constant in combination with aggregate variables (money growth, the market return, exports, and the return to the prewar parity). Figure 4a shows the share of total unemployment explained by shocks to cross-section variation. Reallocation unemployment associated with shocks to CSV accounts for roughly one-quarter of total unemployment on average over the entire time period, and for over one-half of the variance in unemployment. Between 1929 and 1935, the share of unemployment associated with crosssection variation averages over one-third, peaking at 55 percent in 1930 . These results suggest that sectoral shifts accounted for much of the variation in unemployment, and for a moderate share of the level of unemployment on average over the entire period, with a much larger role in the first half of the $1930^{\prime} \mathrm{s}$. These results are particularly striking, since the decomposition uses the equation that is most conservative in assigning explanatory power to the cross-section variation series.

In contrast, unemployment associated with aggregate shocks peaks in 1932 and 1933; this is shown in Figure 4b. The aggregate controls account for much less of the variation in unemployment - close to 30 percent over the entire period and this is attributable primarily to the market return and gold standard variables. 


\section{Conclusion}

Taken together, the point estimates, the impuise response functions, and the decomposition suggest an important role for sectoral shifts in explaining the persistent high unemployment in interwar Britain. The estimates suggest that a standard deviation shock to cross-section variation predicts an increase in unemployment between 1.5 and 1.8 percentage points in 2 years, even after controlling for aggregate shocks. On average, CSV accounts for one-quarter of total unemployment over the interwar period, and over half of unemployment in 1930. It also accounts for over half of the variance in unemployment. In contrast, the measured contribution of aggregate shocks is greatest in 1932-3, and is attributable mainly to the market return and terms-of-trade shocks. The measured contribution of monetary shocks is more moderate, while that of fiscal stimulus and of the benefit-wage ratio is negligible. These results suggest a significant role for sectoral shifts, and accord well with observations that the high levels of interwar unemployment were accompanied by moderate economic growth, high disparities in growth rates between both regions and industries, and massive shifts in the industrial base.

Of course, the results are not conclusive. The chief caveat is that the CSV series may reflect idiosyncratic sectoral responses to aggregate shocks that are not captured in the aggregate variables. To establish definitively whether CSV is a reallocation variable would require an additional variable, such as vacancies, which moves in opposite directions in response to aggregate and sectoral shocks. ${ }^{9} 10$ 
1. A number of papers have been written using similar series since the original 1987 draft of this paper. Brainard and Cutler (1989) developed an analogous series to test for sectoral shifts unemployment in the postwar U.S. economy. A series measuring the variance in total returns was developed by Loungani, Rush, and Tave (1990) for the postwar U.S. economy, and by Loungani and Rush (1991) for the interwar British economy. Cutler (1989) developed a firm cross-section volatility series for the postwar U.S. to test for the importance of nondiversifiable risk in stock prices. In addition, Topel and Weiss (1985) developed a related series as a proxy for workers' expectations about future relative wage uncertainty.

2. See Collins (1982), Cross (1982), Metcalf et. al. (1982), and Hatton (1985).

3. See Brainard and Cutler (1989) for a theoretical treatment of this variant of the sectoral shifts hypothesis, and a more thorough discussion.

4. Sectoral shifts explanations along these lines are closest in spirit to real business cycle explanations such as those advanced by Black (1982) and Lucas and Prescott (1974).

5. Both theoretical and empirical evidence suggests that average wages are a poor reflection of returns to marginal human capital investment.

6. More precisely, they claim a positive correlation between unemployment and employment dispersion could be attributable to aggregate fluctuations if either: (1) industries' trend growth rates and cyclical sensitivities are negatively correlated; or (2) industries differ in their cyclical sensitivities, and labour adjustment costs are higher upward than downward.

7. The series would also work if labour and capital movements were negatively correlated across most industries.

8. The CAPM assumption of complete capital markets may be particularly problematic for the period in question, since the national capital market was thin.

9. See Brainard and Cutler (1989) for a theoretical discussion and empirical results using vacancies to distinguish between the two types of shocks.

10. Unfortunately, vacancy data is unavailable. 


\section{References}

Abraham, Katharine and Lawrence Katz (1986), "Cyclical Unemployment: Sectoral Shifts or Agoregate Disturbances?" Journal of Political Economy,v. 94, n. 3, June, p. 507-522

Aldcroft, D.H. (1967), "Growth in Britain in the Interwar Years: a Reassessment," Economic History Review, v. 20, p. $311-326$.

Barro, R. (1978), "Unanticipated Money, Output, and the Price Level in the U.S.," Journal of Political Economy, August

Benjamin, Daniel K. and Levis A. Kochin (1979), "Searching for an Explanation of Unemployment in Interwar Britain," Journal of Political Economy, v. B7, n. 3, p. 44 1-78.

(19B2), "Unemployment and Unemployment Benefits in Twentieth Century Britain," Journal of Political Economy, v. 90, n. 2, p. 410-36.

Black, Agatha, Earnings and Employment in Britain

Bowley, A.L., G.L. Schwartz, and K.C. Smith (1931). "A New index of Prices of Securities." London and Cambridge Economic Service, Special Memorandum n. 33, v. 9, January

Brainard, S. Lael, and David M. Cutler (1990), "Sectoral Shift and Cyclical Unemployment Reconsidered," NBER Working Paper \#3491, November.

Broadberry, S.N. (1983), "Unemployment in Interwar Britain: A Disequilibrium Approach،" Oxford Economic Papers, 35, p. 463-85.

Burns, E. \{1941), British Unemployment Programs: 1920-38, Social Science Research Council, Washington.

Capie, F.H. and Michael Collins (1982). The Interwar British Economy: A Statistical Abstract, Manchester, Manchester University Press.

Chapman, D. (1953), Wages and Salaries in the United Kingdom, 1920-30, Cambridge University Press.

Collins, Michael (1982), "Unemployment in Interwar Britain: Still Searching for an Explanation," Journal of Political Economy, v. 90, n. 2, p. 369-79.

Cratts, N.F.R., M. MacKinnon, and M. Thomas (1984), "International Trade and Structural Unemployment in Interwar Britain," mimeo, Oxford University.

Cross, Rodney (1982), "How Much Voluntary Unemployment in Interwar Britain," in Comment, Journal of Political Economy, v. 90, n. 2, p. 380-85.

Cutler, David M. (1989), "Stock Market Volatility, Cross Section Volatility, and Stock Returns", MIT, mimeo.

Davis, Steve (1987), "Fluctuations in the Pace of Labor Reallocation," in K. Brunner and A. Metzler (eds.), "Empirical Studies of Velocity, Real Exchange Rates, Unemployment and Productivity," Carnegie-Rochester Conference Series on Public Policy, 27, p. 335-402. 
Deane, Phyllis and B.R. Mitchell, (1971), Abstract of British Historical Sources, Cambridge, Cambridge University Press.

Dimsdale, N.H., Steven J. Nickell, and N. Horsewood (1989), "Real Wages and Unemployment in Britain during the 1930 s," Economic Journal, 99, p. 271-92.

Foinstein, C.H. (1972), Domestic Capital Formation in the U.K., 1920-38, Cambridge, Cambridge University Press.

(1972), National Income, Expenditure, and Output of the U.K.. 1855-65.

Cambridge, Cambridge University Press.

Friedman, Milton, and Anne J. Schwartz (1982), Monetary Trends in the U.S, and the U.K, Chicago, University of Chicago Press.

Hancock, K.J. (1962), "The Reduction of Unemployment as a Problem of Public Policy, 1920-29," Economic History Review, December.

Hatton, T.J. (1985), "The British Labour Market in the 1920's: A Test of the Search Turnover Approach," Explorations in Economic History, v. 22, n. 3, July.

Jones, M.E.F. (1985), "Regional Policy in Interwar Britain," Explorations in Economic History v. 22, n. 4.

Lilien, David (1982a), "Sectoral Shifts and Cyclical Unemployment," Journal of Political Economy, v. 90, n. 4, August, p. 777-793.

Lilien, David (1982b), "A Sectoral Model of the Business Cycle," USC-MRG Working Paper.

Loungani, Prakash, and Mark Rush (1991), "Sectoral Shifts in Interwar Britain," Working Paper, March.

Loungani, Prakash, Mark Rush, and William Tave (1990). "Stock Market Dispersion and Unemployment," Journal of Monetary Economics, June.

Lucas, Robert and Edward Prescott, (1974), "Equilibrium Search and Unemployment," Journal of Economic Theory, 7, February, p. 188-209.

Metcalf, David, Steven J. Nickell, and Nicos Floros (1982),"Still Searching for an Explanation of Unemployment in Interwar Britain," Journal of Political Economy v. 90, n. 2, p. 386-399.

Ormerod, P.A. and G.D.N. Worswick (1982), "Searching for an Explanation of Unemployment in Interwar Britain," Journal of Political Economy, v. 90, n. 2, p. 400-9.

Richardson, H.W. (1961), "The New Industries in 8ritain between the Wars," Oxford Econemic Papers.

Topel, Robert and Laurence Weiss (1985), "Sectoral Uncertainty and Unemployment," in Employment. Unemployment, and Hours of Work.

Von Tunzelmann, G.N. (1982), "Structural Change and Leading Sectors in British Manufacturing. 1907-68," in C.P. Kindleberger and G. Di Tella (eds.), Economics in the Long View, V. III, London, Macmilian. 
Table 1: Regional Unemployment Rates

Percentage of Agaregate UK Unemoloyment Rate

$1913-14 \quad \underline{1929}$

London

$192 \% \quad 50 \%$

Southeast \& East Anglia

$105 \quad 52$

West Midlands

52

East Midlands

71

Northwest

Yorkshire \&umberside

87

71

63

North

$60 \quad 187$

Wales

55

Scotland

- Incorporated in Yorkshire \& Northwest.

Source: Matthews et. al. (1982) 
Table 2: Data

Univariate Statistics

\begin{tabular}{|c|c|c|c|c|c|c|}
\hline \multirow[b]{2}{*}{ Series } & \multirow[b]{2}{*}{ Mean } & \multirow{2}{*}{$\begin{array}{l}\text { Standard } \\
\text { Deviation }\end{array}$} & \multicolumn{4}{|c|}{ Seria| Correlation } \\
\hline & & & $(-1)$ & \pm-21 & $1-31$ & $1-4)$ \\
\hline UNN & 0.112 & 0.035 & 0.771 & 0.358 & -0.024 & -0.263 \\
\hline CSV & 0.057 & 0.073 & 0.203 & 0.132 & 0.022 & 0.012 \\
\hline DRM & 0.032 & 0.040 & 0.368 & -0.261 & -0.221 & -0.060 \\
\hline MRET & 0.026 & 0.207 & 0.162 & -0.290 & -0.191 & -0.223 \\
\hline DEX & -0.023 & 0.090 & -0.069 & -0.081 & 0.245 & 0.091 \\
\hline DGOV & 0.029 & 0.056 & 0.596 & 0.278 & 0.086 & -0.019 \\
\hline $8 w$ & 0.359 & 0.044 & 0.632 & 0.329 & 0.031 & -0.209 \\
\hline EMP & 0.321 & 0.578 & 0.270 & -0.013 & -0.068 & -0.032 \\
\hline
\end{tabular}

\section{Cross-Correlations}

\begin{tabular}{|c|c|c|c|c|c|c|c|c|c|}
\hline Series & Lag & $\begin{array}{l}\text { UNN } \\
0 \\
\end{array}$ & $\begin{array}{c}\text { UNN } \\
1 \\
\end{array}$ & $\begin{array}{c}\text { CSV } \\
1 \\
\end{array}$ & $\begin{array}{c}\text { DRM } \\
1 \\
\end{array}$ & $\begin{array}{l}\text { MRET } \\
1 \\
\end{array}$ & $\begin{array}{c}\text { DEX } \\
1 \\
\end{array}$ & $\begin{array}{c}8 W \\
1 \\
\end{array}$ & $\begin{array}{c}\text { EMP } \\
1 \\
\end{array}$ \\
\hline UNN & 1 & 0.778 & & & & & & & \\
\hline CSV & 1 & 0.703 & 0.354 & & & & & & \\
\hline DRM & 1 & -0.124 & 0.240 & -0.109 & & & & & \\
\hline MRET & 1 & -0.536 & -0.377 & -0.292 & -0.013 & & & & \\
\hline DEX & 1 & -0.514 & -0.348 & -0.344 & -0.348 & 0.738 & & & \\
\hline BW & 1 & 0.046 & -0.141 & 0.097 & -0.623 & 0.283 & -0.021 & & \\
\hline EMP & 1 & 0.014 & 0.140 & -0.054 & 0.550 & -0.645 & -0.332 & -0.791 & \\
\hline DGOV & 1 & 0.068 & -0.056 & -0.060 & -0.466 & -0.198 & -0.330 & 0.650 & -0.218 \\
\hline
\end{tabular}

Note: Definitions of the variables are given in the text. Data are annual from 1921 to 1938. 
Tabte 3: Iime Soecification of the Unemolovment Equation

\begin{tabular}{|c|c|c|c|c|}
\hline & $\begin{array}{c}1 \\
\text { UNN } \\
\end{array}$ & $\begin{array}{l}2 \\
\text { UNN } \\
\end{array}$ & $\begin{array}{l}3 \\
\text { UNN } \\
\end{array}$ & $\stackrel{4}{\text { DUN }}$ \\
\hline$R^{2}$ & 0.786 & 0.890 & 0.785 & 0.520 \\
\hline $\begin{array}{l}\text { DURBIN- } \\
\text { WATSON }\end{array}$ & 1.46 & & & \\
\hline CONST. & $\begin{array}{c}0.071 \\
(0.008)\end{array}$ & $\begin{array}{c}0.035 \\
(0.013)\end{array}$ & $\begin{array}{c}0.082 \\
(0.015)\end{array}$ & $\begin{array}{c}0.003 \\
(0.008)\end{array}$ \\
\hline Csvio) & $\begin{array}{c}0.093 \\
(0.060)\end{array}$ & $\begin{array}{c}0.098 \\
(0.043)\end{array}$ & $\begin{array}{c}0.094 \\
(0.061)\end{array}$ & $\begin{array}{r}0.083 \\
(0.047)\end{array}$ \\
\hline $\operatorname{csv}(1)$ & $\begin{array}{c}0.274 \\
(0.060)\end{array}$ & $\begin{array}{c}0.209 \\
(0.048)\end{array}$ & $\begin{array}{c}0.247 \\
(0.065)\end{array}$ & $\begin{array}{r}0.084 \\
(0.055)\end{array}$ \\
\hline $\operatorname{csv}(2)$ & $\begin{array}{c}0.258 \\
(0.070)\end{array}$ & $\begin{array}{c}0.116 \\
(0.067)\end{array}$ & $\begin{array}{c}0.161 \\
(0.065)\end{array}$ & $\begin{array}{l}-0.046 \\
(0.060)\end{array}$ \\
\hline DAM(O) & $\begin{array}{c}0.078 \\
(0.2051\end{array}$ & $\begin{array}{l}-0.085 \\
|0.156|\end{array}$ & $\begin{array}{c}0.208 \\
(0.187)\end{array}$ & $\begin{array}{l}-0.228 \\
|0.165|\end{array}$ \\
\hline DAM(1) & $\begin{array}{l}-0.004 \\
10.1331\end{array}$ & $\begin{array}{l}-0.128 \\
(0.103)\end{array}$ & $\begin{array}{l}-0.078 \\
(0.176)\end{array}$ & $\begin{array}{l}-0.162 \\
(0.112)\end{array}$ \\
\hline UNN(1) & & $\begin{array}{c}0.504 \\
(0.156)\end{array}$ & & \\
\hline$\rho$ & & & $\begin{array}{c}0.621 \\
(0.330)\end{array}$ & \\
\hline DUN(1) & & & & $\begin{array}{c}0.260 \\
10.2811\end{array}$ \\
\hline
\end{tabular}

Note: Table 3 reports regressions of the unemployment rate on contemporaneous and lagoed values of CSV and DRM at annual frequencies for different time specifications. Definitions of the variables are given in the text. Columns (1) through (4) correspond to Equations (5) through (8) in the text respectively. 
Table 4: Unemoloyment Equations with Cross Section Variation

\begin{tabular}{|c|c|c|c|c|c|c|}
\hline & 1 & 2 & 3 & 4 & -5 & $\theta$ \\
\hline$R^{2}$ & 0.887 & 0.890 & 0.931 & 0.978 & 0.905 & 0.976 \\
\hline CONST. & $\begin{array}{c}0.040 \\
(0.012)\end{array}$ & $\begin{array}{c}0.035 \\
(0.013)\end{array}$ & $\begin{array}{c}0.043 \\
(0.012)\end{array}$ & $\begin{array}{c}0.114 \\
(0.019)\end{array}$ & $\begin{array}{c}0.029 \\
10.0121\end{array}$ & $\begin{array}{c}0.144 \\
(0.034)\end{array}$ \\
\hline Csv(0) & $\begin{array}{c}0.104 \\
(0.043)\end{array}$ & $\begin{array}{c}0.098 \\
(0.043)\end{array}$ & $\begin{array}{c}0.083 \\
(0.038)\end{array}$ & $\begin{array}{c}0.170 \\
10.0311\end{array}$ & $\begin{array}{c}0.053 \\
(0.046)\end{array}$ & $\begin{array}{c}0.210 \\
(0.051)\end{array}$ \\
\hline Csv(1) & $\begin{array}{c}0.226 \\
(0.047)\end{array}$ & $\begin{array}{c}0.209 \\
(0.048)\end{array}$ & $\begin{array}{c}0.154 \\
(0.042)\end{array}$ & $\begin{array}{c}0.240 \\
(0.033)\end{array}$ & $\begin{array}{c}0.158 \\
(0.057)\end{array}$ & $\begin{array}{c}0.258 \\
(0.042)\end{array}$ \\
\hline $\operatorname{csv}(2)$ & $\begin{array}{c}0.150 \\
(0.061)\end{array}$ & $\begin{array}{c}0.116 \\
(0.067)\end{array}$ & $\begin{array}{c}0.081 \\
(0.059)\end{array}$ & $\begin{array}{c}0.113 \\
(0.033)\end{array}$ & $\begin{array}{c}0.097 \\
(0.065)\end{array}$ & $\begin{array}{c}0.120 \\
(0.037)\end{array}$ \\
\hline UNN(1) & $\begin{array}{c}0.377 \\
10.1311\end{array}$ & $\begin{array}{c}0.504 \\
(0.156)\end{array}$ & $\begin{array}{c}0.506 \\
(0.131)\end{array}$ & $\begin{array}{l}-0.022 \\
10.1531\end{array}$ & $\begin{array}{c}0.545 \\
(0.152)\end{array}$ & $\begin{array}{l}-0.285 \\
(0.278)\end{array}$ \\
\hline DRM(O) & & $\begin{array}{l}-0.085 \\
(0.156)\end{array}$ & $\begin{array}{l}-0.097 \\
(0.172)\end{array}$ & $\begin{array}{l}-0.165 \\
(0.099)\end{array}$ & $\begin{array}{c}0.006 \\
(0.155)\end{array}$ & $\begin{array}{l}-0.172 \\
(0.111)\end{array}$ \\
\hline DRM(1) & & $\begin{array}{l}-0.128 \\
(0.103)\end{array}$ & $\begin{array}{l}-0.018 \\
(0.093)\end{array}$ & $\begin{array}{l}-0.223 \\
(0.074)\end{array}$ & $\begin{array}{l}-0.052 \\
(0.140)\end{array}$ & $\begin{array}{l}-0.225 \\
10.0831\end{array}$ \\
\hline MRET(O) & & & $\begin{array}{l}-0.019 \\
(0.032)\end{array}$ & $\begin{array}{c}0.068 \\
(0.029)\end{array}$ & & $\begin{array}{c}0.112 \\
(0.047)\end{array}$ \\
\hline MRET(1) & & & $\begin{array}{l}-0.053 \\
(0.029)\end{array}$ & $\begin{array}{l}-0.125 \\
10.0241\end{array}$ & & $\begin{array}{l}-0.145 \\
(0.034)\end{array}$ \\
\hline GOLD & & & & $\begin{array}{l}-0.034 \\
(0.009)\end{array}$ & & $\begin{array}{l}-0.048 \\
(0.015)\end{array}$ \\
\hline DEX.(O) & & & & & $\begin{array}{l}-0.130 \\
(0.070)\end{array}$ & $\begin{array}{l}-0.013 \\
(0.046)\end{array}$ \\
\hline DEX(1) & & & & & $\begin{array}{l}-0.016 \\
(0.066)\end{array}$ & $\begin{array}{l}-0.074 \\
(0.061)\end{array}$ \\
\hline $\begin{array}{l}\text { F Stat } \\
\text { CSV }_{1=0}\end{array}$ & 0.001 & 0.003 & 0.022 & 0.002 & 0.111 & 0.016 \\
\hline
\end{tabular}

Note: Table 4 reports OLS regressions of unemployment on contemporaneous and lagoed values of CSV and aggregate controls at annual frequencies. The variables are defined in the text. The specification corresponds to Equation (6), with additional independent variables. 
Table 4: Unemoloyment Eouations with Cross Section Variation

(cont.)

\begin{tabular}{|c|c|c|c|}
\hline & 7 & 8 & 9 \\
\hline$R^{2}$ & 0.868 & 0.876 & 0.926 \\
\hline CONST. & $\begin{array}{c}0.034 \\
(0.014)\end{array}$ & $\begin{array}{c}0.097 \\
(0.079)\end{array}$ & $\begin{array}{c}0.003 \\
(0.016)\end{array}$ \\
\hline $\operatorname{csv}(0)$ & $\begin{array}{c}0.105 \\
(0.049)\end{array}$ & $\begin{array}{c}0.085 \\
(0.047)\end{array}$ & $\begin{array}{c}0.217 \\
(0.067)\end{array}$ \\
\hline $\operatorname{csv}(1)$ & $\begin{array}{c}0.222 \\
(0.058)\end{array}$ & $\begin{array}{c}0.194 \\
(0.053)\end{array}$ & $\begin{array}{c}0.016 \\
(0.086)\end{array}$ \\
\hline $\operatorname{csv}(2)$ & $\begin{array}{c}0.129 \\
(0.076)\end{array}$ & $\begin{array}{c}0.077 \\
(0.082)\end{array}$ & $\begin{array}{l}-0.037 \\
(0.079)\end{array}$ \\
\hline UNN(1) & $\begin{array}{c}0.451 \\
(0.193)\end{array}$ & $\begin{array}{c}0.556 \\
(0.174)\end{array}$ & $\begin{array}{c}0.916 \\
(0.198)\end{array}$ \\
\hline DRM(0) & $\begin{array}{l}-0.025 \\
(0.223)\end{array}$ & $\begin{array}{l}-0.081 \\
(0.168 \mid\end{array}$ & $\begin{array}{l}-0.473 \\
(0.161)\end{array}$ \\
\hline DRM(1) & $\begin{array}{l}-0.081 \\
(0.132)\end{array}$ & $\begin{array}{l}-0.229 \\
(0.167)\end{array}$ & $\begin{array}{l}-0.473 \\
10.1831\end{array}$ \\
\hline
\end{tabular}

DGOV(0) $\quad 0.052$

DGov(1) $\begin{gathered}\mathbf{1 0 . 1 8 8 )} \\ 0.014\end{gathered}$

(0.120)

$\begin{array}{cc}\text { BW(0) } & -0.320 \\ & 10.3171 \\ \text { BW(1) } & 0.159 \\ & 10.198)\end{array}$

EMP(O) $\quad-0.032$

10.0411

0.159

(0.065)

$-0.025$

(0.016)

$\begin{array}{llll}\text { F Stat } & & & \\ \text { CSV }_{i-0} & 0.018 & 0.023 & 0.028 \\ \text { EMP }_{i=0} & & & 0.158\end{array}$

Note: Table 4 reports OLS regressions of unemployment on contemporaneous and lagged values of CSV and aggregate controls at annual frequencies. The variables are defined in the text. The specification corresponds to Equation (6), with additional independent variables. 

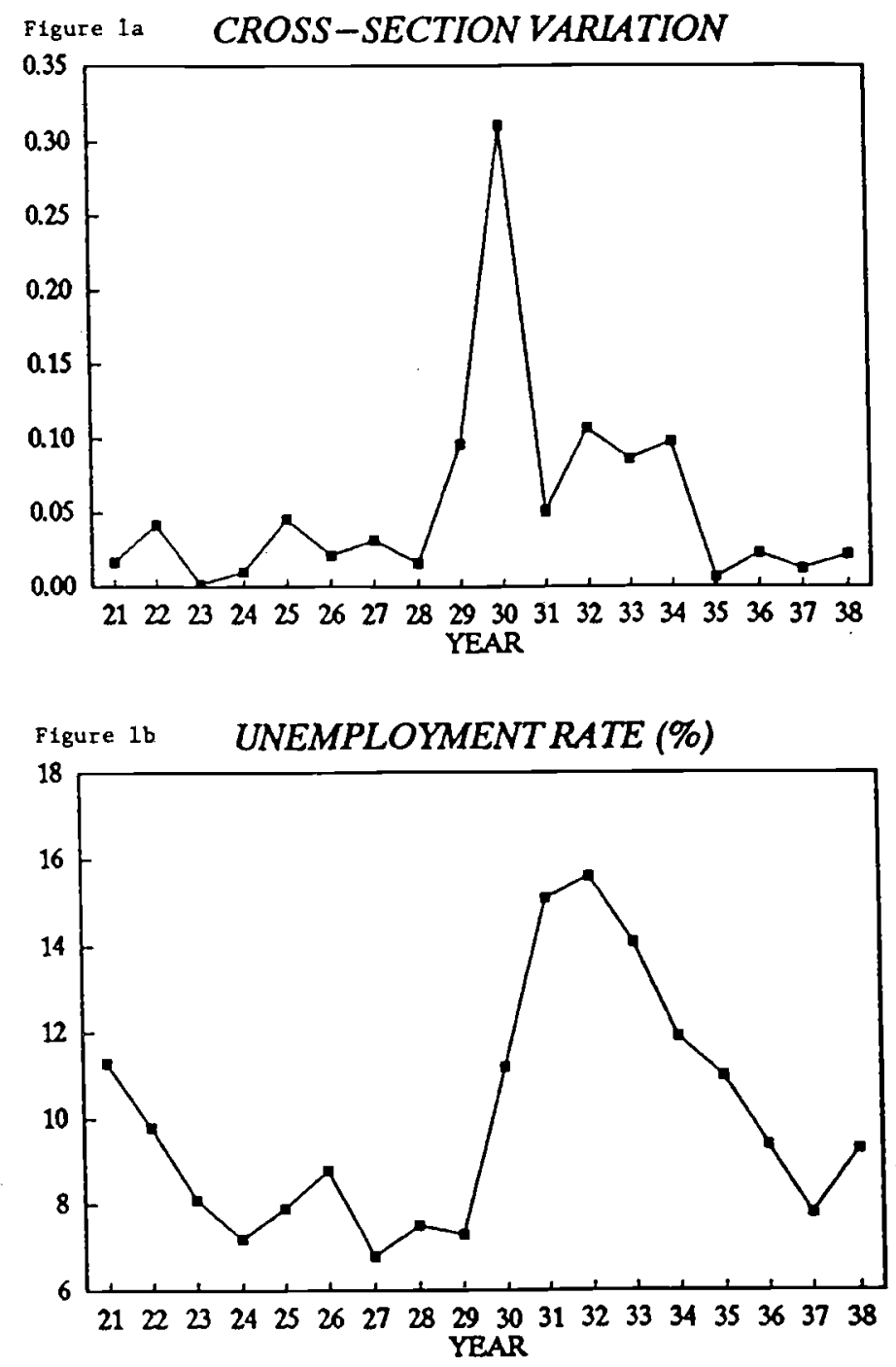
Fig. 2

UNEMPLOYMENT RESPONSE TO CSV SHOCK UNIVARLATE EQUATION

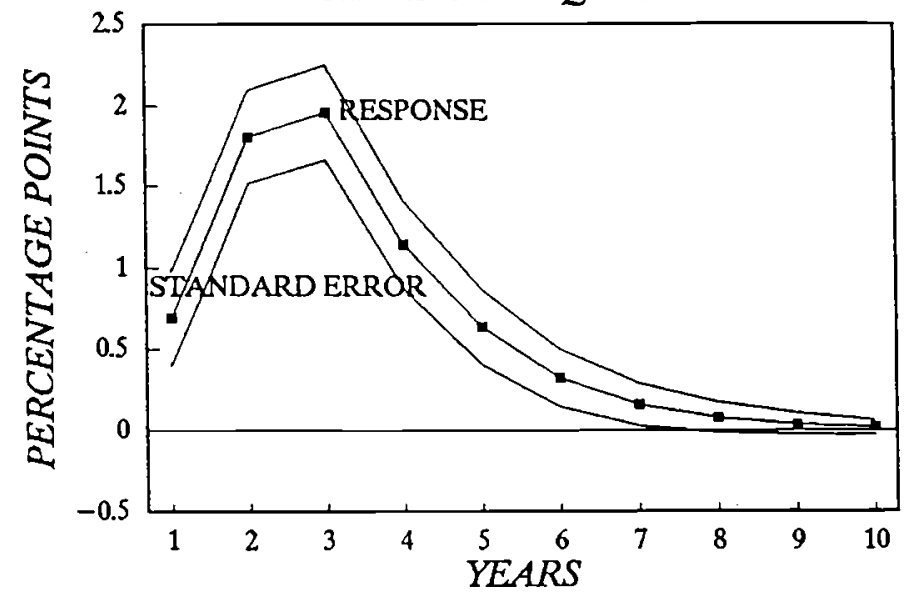

F1g. 3a

UNEMPLOYMENT RESPONSE TO CSV SHOCK MULTIVARIATE EQUATION

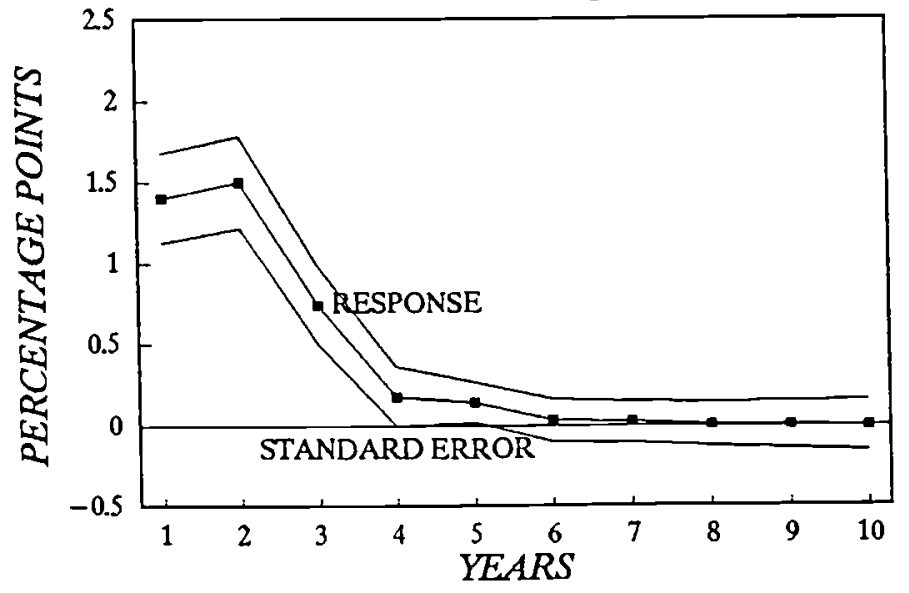


Fig. 3b

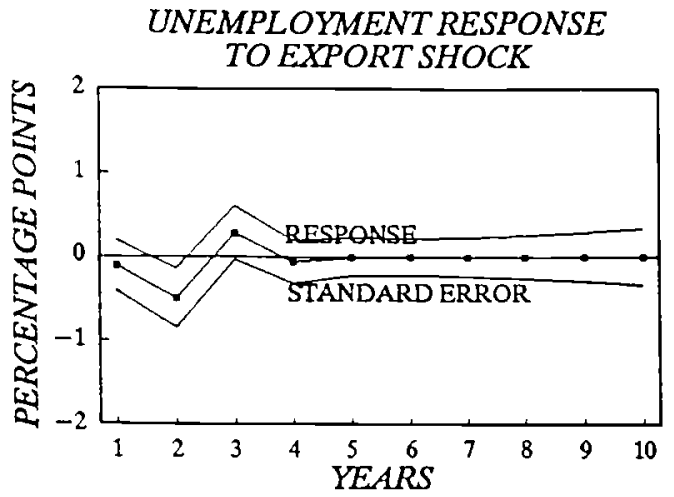

Fig. 3c

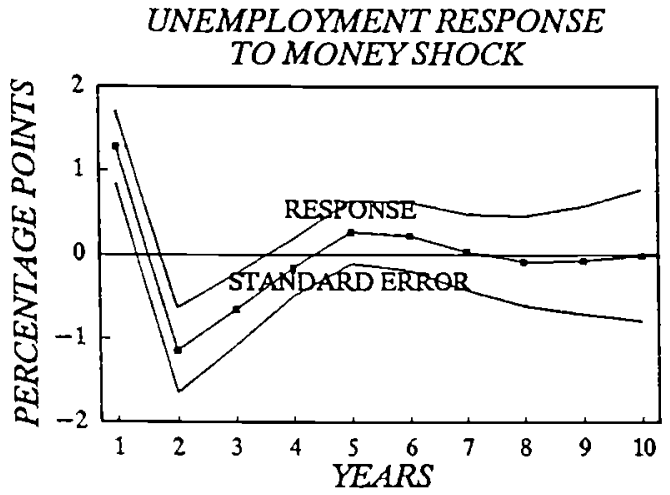

F1r. $3 d$

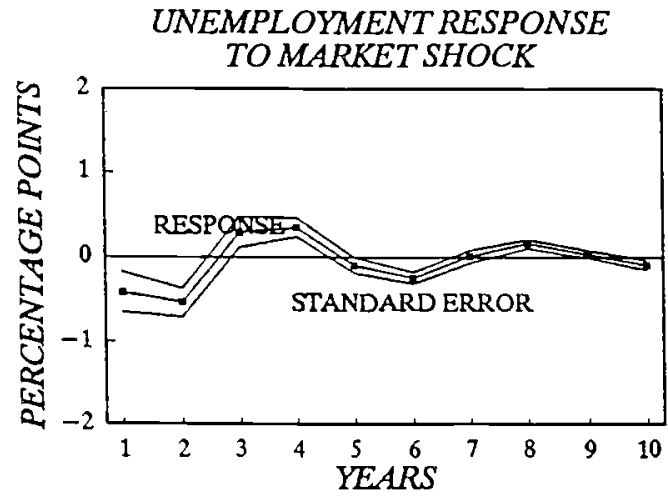




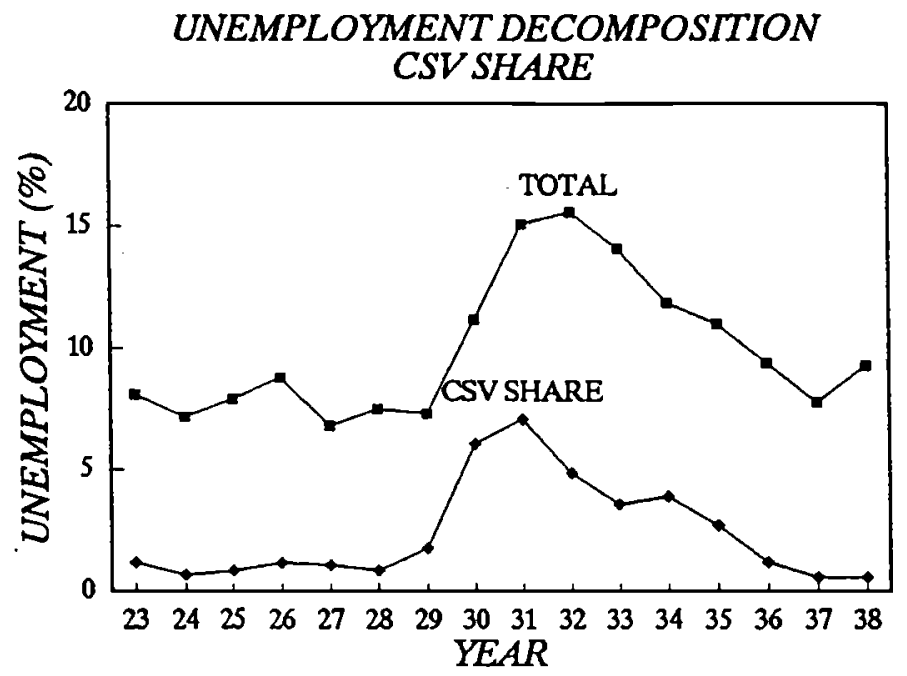

Fir. $4 b$

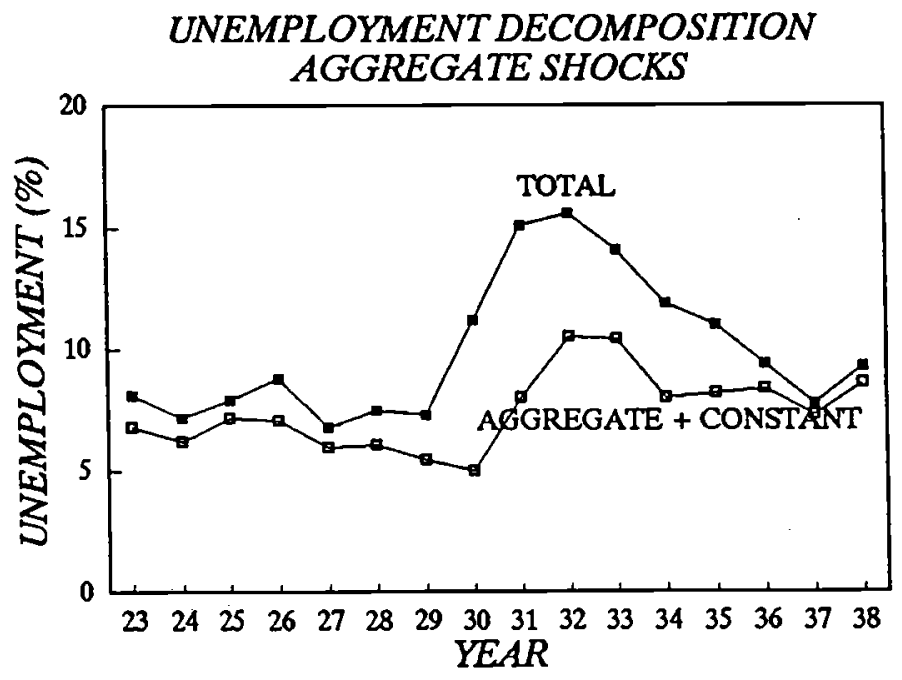




$\begin{array}{cc}\text { Year } & \text { CSV } \\ \text { 21 } & 0.017 \\ 22 & 0.042 \\ 23 & 0.003 \\ 24 & 0.010 \\ 25 & 0.046 \\ 26 & 0.021 \\ 27 & 0.032 \\ 28 & 0.016 \\ 29 & 0.096 \\ 30 & 0.310 \\ 31 & 0.051 \\ 32 & 0.106 \\ 33 & 0.086 \\ 34 & 0.098 \\ 35 & 0.007 \\ 36 & 0.023 \\ 37 & 0.012 \\ 38 & 0.022\end{array}$

\section{Appendix: Data Sources}

\section{Series}

Name Description

UNN Aggregate Unemployment Rate/Employment Rate CSV Employment-weighted Variance in Industry Excess Returns

DRM Log Change in Real Money Supply

DEX Change in Export Revenues in 1938 Prices

DGOV Change in Real Government Expenditures

MRET Return on the Market Portfolio

BW Average Ratio of Unemployment Benefits to Wage

EMP Employment-weighted Variance in Sectoral Employment Growth

PINDX GNP Deflator Index

PBOR Change in Central Government Debt

\section{Source}

Feinstein, 1972

Described in text

Friedman and Schwartz 1982

Feinstein, 1972

Feinstein, 1972

London Times and

London Cambridge Economic Service Benefits: Burns, 1941

Wages: Chapman, 1953

Employment data from Feinstein, 1972

Feinstein, 1972

Feinstein, 1972 